\title{
CARA SISWA MENGATASI KECEMASAN DALAM MENGHADAPI UJIAN (Studi Deskriptif Terhadap Siswa Kelas VII di SMP N 12 Padang)
}

\author{
Emeliya Hardi, M.Pd \\ Jurusan Bimbingan dan Konseling IAIN Batusangkar \\ Email : emeliyahardi@iainbatusangkar.ac.id
}

\begin{abstract}
Learning activities aim to achieve a change, to find out then at the end of the learning process in the teaching and learning activities an assessment process is carried out through the implementation of the exam. Exams that are done in an uncomfortable mood often cause anxiety that can disrupt the smoothness of teaching and learning activities. students have different ways to deal with anxiety. The purpose of this study is to reveal how students overcome anxiety in the face of examinations. The method of this research is carried out using descriptive methods with quantitative approaches. The data in this study were collected using a questionnaire. The study population was seventh grade students at SMP 12 Padang in the 2009/2010 school year. The sample of this study amounted to 63 people, with the sampling technique namely Simple random sampling.

The results of the study show that students overcome anxiety in facing exams with;1) Repeat the lesson is good, namely by trying to master the subject matter, 2) Setting the learning time is not good, namely by repeating the lesson 10-15 minutes after the class is over. 3) Complete notes to repeat the lesson. 4) A comfortable learning environment, namely by maintaining the calm of the house in order to learn well and the attention of parents in learning activities at home. 5) Practicing techniques for examinations is very good, namely by praying before taking the exam.
\end{abstract}

\section{Keywords: Anxiety, Facing Exams}

\begin{abstract}
Abstrak Kegiatan belajar bertujuan untuk mencapai suatu perubahan, untuk mengetahuinya maka pada akhir proses belajar dalam kegiatan belajar mengajar dilakukan proses penilaian melalui pelaksanaan ujian. Ujian yang dikerjakan dengan suasana hati tidak nyaman seringkali menimbulkan kecemasan yang dapat mengganggu kelancaran dalam kegiatan belajar mengajar. siswa memiliki cara yang berbeda-beda untuk mengatasi kecemasan. Tujuan penelitian ini untuk mengungkapkan bagaimana cara siswa mengatasi kecemasan dalam menghadapi ujian. Metode penelitian ini dilakukan dengan menggunakan metode deskriptif dengan pendekatan kuatitatif. Data dalam penelitian ini dikumpulkan dengan menggunakan angket. Populasi penelitian adalah siswa kelas VII di SMPN 12 Padang pada tahun ajaran 2009/2010. Sampel penelitian ini berjumlah 63 orang, dengan teknik pengambilan sampel yaitu Simple random sampling.

Hasil penelitian menunjukkan bahwa siswa mengatasi kecemasan dalam menghadapi ujian dengan; 1) Mengulang pelajaran sudah baik yaitu dengan berusaha menguasai materi pelajaran, 2) Mengatur waktu belajar kurang baik yaitu dengan mengulang pelajaran 10-15 menit setelah kelas selesai. 3)Melengkapi catatan untuk mengulang pelajaran. 4) Lingkungan belajar yang nyaman yaitu dengan menjaga ketenangan rumah agar dapat belajar dengan baik dan perhatian orang tua pada kegiatan belajar di rumah. 5) Melatih teknik untuk ujian sangat baik yaitu dengan berdoa sebelum mengikuti ujian.
\end{abstract}

Kata kunci: Metode, Tahfiz, Miftahul Jannah

\section{PENDAHULUAN}

Pendidikan sebagai suatu proses psikologis, tidak dapat dipisahkan dari kegiatan belajar mengajar. Hal ini sesuai yang diungkapkan Ahmadi dan Supriyono (1991: 118) bahwa "dalam keseluruhan proses pendidikan, kegiatan belajar merupakan kegiatan yang paling pokok. 
Secara umum belajar dapat dipengaruhi oleh tiga faktor penting, yaitu faktor internal (dalam diri), eksternal (luar diri) dan pendekatan belajar". Sejalan dengan itu Syah (1997: 132) juga mengemukakan bahwa "faktor yang berasal dari dalam diri peserta didik meliputi dua aspek, yaitu aspek psikologis (yang bersifat jasmaniah) dan aspek psikologis (yang bersifat rohaniah)".

Berhasil atau tidaknya pencapaian tujuan pendidikan banyak tergantung kepada berbagai faktor yang mempengaruhi proses belajar selama berlangsungnya Kegiatan Belajar Mengajar (KBM) sebagai bagian dari aspek psikologis, faktor emosional sangat berperan dalam menunjang keberhasilan ataupun kegagalan siswa dalam mencapai prestasi belajarnya. Berbagai masalah dapat muncul apabila persiapan kurang matang sehingga timbul rasa cemas, gelisah, dan bahkan takut menghadapi ujian.

Akhmad Sudrajat (2008:1) mengungkapkan bahwa di sekolah, banyak faktor-faktor pemicu timbulnya kecemasan pada diri siswa. Target kurikulum yang terlalu tinggi, iklim pembelajaran yang tidak kondusif, pemberian tugas yang sangat padat, serta sistem penilaian ketat dan kurang adil dapat menjadi faktor penyebab timbulnya kecemasan yang bersumber dari faktor kurikulum. Begitu juga sikap dan perlakuan guru yang kurang bersahabat dan kurang kompeten merupakan sumber penyebab timbulnya kecemasan pada diri siswa yang bersumber dari faktor guru. Penerapan disiplin sekolah yang ketat dan lebih mengedepankan hukuman, iklim sekolah yang kurang nyaman, serta sarana dan prasarana belajar yang sangat terbatas juga merupakan faktor- faktor pemicu terbentuknya kecemasan pada siswa yang bersumber dari faktor manajemen sekolah.

Berdasarkan hasil wawancara pada tanggal 19 Februari 2010 dengan 9 (sembilan) orang siswa kelas VII di SMPN
12 Padang, yang terdiri dari 4 (empat) orang siswa kelas RSBI, dan 5 (lima) orang siswa reguler, diketahui pada umumnya mereka merasa cemas sebelum dan saat menghadapi tes/ujian. Dengan bertambahnya jumlah mata pelajaran, cara menjawab di lembar jawaban ABO dan perubahan lainnya mereka takut dan cemas jika tidak bisa menjawab soal ujian dan mengakibatkan nilai yang mereka peroleh rendah. Mereka juga cemas jika tidak dapat naik kelas. Ada yang mengatakan bahwa saat ujian karena cemasnya mereka tidak dapat konsentrasi menjawab soal ujian sehingga jawaban yang mereka tulis kadang tidak pas dengan jawaban yang seharusnya. Ada juga siswa yang menyatakan ia cemas saat ujian atau ulangan dan mengakibatkan keadaan fisik terganggu seperti sering buang air kecil dan tangan mereka basah.

Bertitik tolak dari fenomena yang telah diuraikan di atas, peneliti ingin mengetahui dan mengungkapkan bagaimana "Cara Siswa Mengatasi Kecemasan dalam Menghadapi Ujian".

\section{Kecemasan Menghadapi Ujian.}

Kecemasan dalam menghadapi ujian dapat dialami oleh setiap orang, pada kenyataanya kecemasan yang kadarnya sedikit itu penting untuk meningkatkan prestasi belajar. Kecemasan yang terlalu berat dapat membuat individu menjadi tidak semakin memahami sesuatu yang pernah diingatnya. Jika hal ini menjadi masalah bagi individu. maka perlu pada individu untuk mempertanyakan tentang apa yang menjadi penyebab timbulnya kecemasan.

Tingkat kecemasan siswa dalam menghadapi ujian sangat berpengaruh terhadap tingkah laku siswa, seperti yang diungkapkan Sarason (dalam Slameto 1988:188) bahwa:

Tingkah laku termasuk prestasi yang dicapai seseorang individu dipengaruhi oleh rasa cemas, yaitu siswa dengan kecemasan yang tinggi tidak berprestasi sebaik siswa 
dengan tingkat kecemasan yang rendah, pada beberapa jenis tugas yang ditandai dengan tantangan, kesulitan. penilaian prestasi, dan batasan waktu. Diberikan suatu tugas yang meminta pemikiran analitis pada siswa dengan tingkat kecemasan yang tinggi dan rendah, dengan memberikan batas waktu dan tanpa batas waktu, siswa-siswa dengan tingkat kecemasan yang tinggi membuat lebih banyak kesalahan pada suatu waktu yang terbatas, sedangkan siswa-siswa dengan tingkat kecemasan rendah lebih banyak membuat kesalahan dalam situasi waktu yang tidak terbatas. Interaksi ini jelas menunjukkan kelemahan siswa-siswa dengan kecemasan tinggi dalam situasi yang sangat menekan.

Kecemasan yang terkelola dengan baik dimungkinkan akan mengimbas kepada hasil belajar siswa. Untuk menunjang pencapaian prestasi belajar yang tinggi, pihak sekolah hendaknya mampu mengoptimalkan kemampuan siswa dengan sebaik-baiknya dengan cara memberikan kesempatan dan peluang kepada siswa agar mereka merasa terbebas dan rasa cemas yang berlebihan.

Cara Mengatasi Kecemasan Menghadapi Ujian.

Hasbullah (1995:112) menjelaskan bahwa perasaan cemas menjelang ujian dapat terjadi jika tidak siap menghadapi ujian. Perasaan ini seringkali menghapuskan apa yang sudah kita ketahui dan kuasai dari pikiran kita. Oleh karena itu persiapan jauhjauh hari sangat penting.

untuk mengatasi kecemasan dalam menghadapi ujian maka diperlukan teknik belajar yang baik. Caron Grainger (1999: 45) mengemukakan teknik belajar yang baik yaitu: 1)Mengulang pelajaran, 2) Belajar pada waktu yang terbaik, 3) Membuat catatan pelajaran, 4) Menata lingkungan belajar senyaman mungkin, 5) Melatih teknik untuk ujian.

\section{METODE}

Penelitian ini adalah penelitian deskriptif dengan metode kuantitatif. penelitian ini, akan mendeskripsikan data tentang instrumen penelitian apa adanya, yaitu tentang cara siswa mengatasi kecemasan dalam menghadapi ujian.

\section{HASIL \& PEMBAHASAN}

Berdasarkan pengolahan yang telah dilakukan, data dianalisis berdasarkan indikator yang diajukan, adapun hasilnya sebagai berikut:

1. Cara siswa mengatasi kecemasan dalam menghadapi ujian pada indikator mengulang pelajaran, paling banyak siswa memilih kategori selalu berusaha menguasai materi pelajaran dan sering mengulang kembali semua mata pelajaran yang di ujikan (54\%), selanjutnya siswa mengatasi kecemasan dengan membuat pertanyaan pada setiap bab pelajaran pada kategori kadangkadang (52\%).

2. Cara siswa mengatasi kecemasan dalam menghadapi ujian pada indikator mengatur waktu untuk belajar, paling banyak siswa memilih kategori kadangkadang mengulang pelajaran 10-15 menit setelah kelas selesai (51\%).

3. Cara siswa mengatasi kecemasan dalam menghadapi ujian pada indikator membuat catatan pelajaran, paling banyak siswa memilih kategori selalu melengkapi catatan untuk mengulang pelajaran $(70 \%)$.

4. Cara siswa mengatasi kecemasan dalam menghadapi ujian pada indikator lingkungan yang nyaman, paling banyak siswa memilih kategori selalu orangtua 
memperhatikan kegiatan belajar di rumah $(62 \%)$.

5. Cara siswa mengatasi kecemasan dalam menghadapi ujian pada indikator melatih teknik untuk ujian, paling banyak siswa memilih kategori selalu berdoa sebelum mengikuti ujian (86\%).

Pembahasan ini dilakukan berdasarkan kepada pertanyaan penelitian yang telah dikemukakan pada bab I yaitu:

1. Cara siswa mengulang pelajaran.

Berdasarkan hasil analisis data dapat disimpulkan bahwa siswa mengatasi kecemasan dalam hal mengulang pelajaran sudah baik. Terlihat dari hasil analisis data yang berkenaan dengan mengulang pelajaran siswa memilih paling banyak dengan selalu berusaha menguasai materi pelajaran dan sering mengulang kembali semua mata pelajaran yang di ujiankan. Dalam hal ini dapat diketahui bahwa siswa yang sudah menguasai materi dengan mengulang semua mata pelajaran yang di ujiankan maka mereka akan siap untuk menghadapi ujian. Terlihat juga bahwa siswa mengatasi kecemasan dengan membuat pertanyaan pada setiap bab pelajaran sudah baik. Tetapi mereka baru kadang-kadang melakukannya, untuk itu siswa hendaknya dapat mengulang pelajaran dengan membuat pertanyaan pada setiap bab pelajaran, karena materi yang di ujiakan tidak terlepas dari apa yang telah dipelajari pada setiap bab pelajaran.

Hal di atas sesuai dengan pendapat Hasbullah (1993: 112) bahwa "Persiapan mendekati musim ujian itu dilakukan dengan belajar rutin setiap hari, memiliki ringkasan yang sistematis setiap pelajaran yang akan di ujiankan, menyusun jadwal, mengulang mata pelajaran, membuat pertanyaan dan membahas soal-soal tahun lalu yang berkaitan dengan ujian”. Dari uraian ini terlihat bahwa siswa mengatasi kecemasannya dalam menghadapi ujian dengan mengulang pelajaran.

\section{Mengatur waktu belajar}

Berdasarkan hasil analisis data dapat disimpulkan bahwa siswa mengatasi kecemasan dengan mengatur waktu untuk belajar sudah baik. Terlihat dari hasil analisis data yang berkenaan dengan mengatur waktu untuk belajar, siswa memilih paling banyak pada kategori kadang-kadang mengulang pelajaran 10-15 menit setelah kelas selesai. Dalam hal ini siswa tidak seluruhnya baik dalam mengatur waktu untuk belajar karena dari lima item pernyataan, hanya satu item yang persentasenya di atas $50 \%$ dan alternatif jawaban pada bagian kadang-kadang.

Pengaturan atau pembagian waktu sangat penting dalam menghadapi ujianujian, dengan demikian siswa dapat memberikan porsi yang sesuai dengan bobot dan banyaknya dari setiap mata pelajaran. Asosiasi Konsuler Negara Bagian New York (NYSCA) (dalam Hasbullah 1993:62) menyatakan bahwa belajar dengan jadwal akan melatih kita untuk berkonsentrasi, bekerja cepat dan lengkap dan harus diperhatikan bahwa di dalam membuat jadwal belajar, setiap minggu tiap mata pelajaran harus mendapat jatah.

3. Membuat catatan pelajaran

Berdasarkan hasil analisis data dapat disimpulkan bahwa siswa mengatasi kecemasan dengan membuat catatan pelajaran sudah baik. Terlihat dari hasil analisis data yang berkenaan dengan membuat catatan pelajaran, siswa memilih paling banyak pada kategori selalu melengkapi catatan untuk mengulang pelajaran. Persiapan mengikuti ujian tidak dapat dilakukan begitu saja, tanpa mempersiapkan diri dengan materi belajar yang baik. Untuk itu perlu usaha belajar yang sungguh-sungguh agar punya 
kemampuan menguasai materi belajar, dengan membuat catatan pada buku tertentu untuk masing-masing mata pelajaran. Sesuai menurut Hasbullah (1994: 76) " format catatan yang baik dan lengkap akan membantu anda mempelajari atau mengulang pelajaran dengan cepat, usahakan anda mengerti apa-apa yang dijelaskan sebelum dicatat". Jadi dengan demikian jelaslah bahwa membuat catatan pelajaran dapat membantu siswa mengatasi rasa cemas dalam menghadapi ujian.

\section{Lingkungan belajar yang nyaman}

Berdasarkan hasil analisis data dapat disimpulkan bahwa siswa mengatasi kecemasan dengan lingkungan belajar yang nyaman sudah baik. Terlihat dari hasil analisis data siswa memilih paling banyak pada kategori selalu dengan perhatian orangtua pada kegiatan belajar di rumah. Perhatian orangtua dan anggota keluarga lainnya sangat mempengaruhi siswa dalam kesiapannya untuk menghadapi ujian.

Hal di atas sesuai menurut Herman Nirwana, dkk (2006: 140) bahwa "lingkungan sosio-emosional siswa yang dapat mengganggu kelancaran belajar siswa meliputi, antara lain: 1) hubungan guru dengan siswa, dan sesama siswa, 2) hubungan dan perlakuan anggota keluarga, 3) suasana lingkungan belajar (di rumah dan sekolah), 4) pergaulan dengan temanteman di luar sekolah, 5) kondisi geografis tempat tinggal dan sekolah". Jadi dengan demikian jelaslah bahwa siswa mengatasi kecemasannya dengan lingkungan belajar yang nyaman. Dengan adanya lingkungan yang nyaman, sepeti cukupnya sarana dan prasarana, adanya dukungan dari keluarga, dukungan dari guru dan sekolah dapat membantu siswa mengatasi rasa cemas dalam menghadapi ujian.

5. Melatih teknik untuk ujian

Berdasarkan hasil analisis data dapat disimpulkan bahwa siswa mengatasi kecemasan dengan melatih teknik untuk ujian sangat baik. Terlihat dari hasil analisis data siswa memilih paling banyak dengan berdoa sebelum mengikuti ujian.

Melatih teknik untuk ujian sangat penting bagi siswa dalam menghadapi ujian, salah satunya dengan berdoa sebelum mengikuti ujian. Hal ini juga dapat membantu siswa mengatasi kecemasan dalam menghadapi ujian. Menurut Hasbullah (1995: 119) jika sebelum mengikuti ujian merasa gugup/ stress, bacalah doa minta kepada tuhan sesuai dengan kepercayaan masing-masing, agar ditenangkan hati, dilapangkan dada dan dibukakan akal pikiran. Pada waktu mengikuti ujian, ikutilah petunjuk-petunjuk yang diberikan dalam naskah ujian maupun yang disampaikan oleh pengawas.

\section{SIMPULAN}

Berdasarkan hasil penelitian yang telah diperoleh, maka dapat disimpulkan bahwa siswa mengatasi kecemasan menghadapi ujian dengan

1. Mengulang pelajaran sudah baik yaitu dengan berusaha menguasai materi pelajaran.

2. Mengatur waktu belajar kurang baik yaitu dengan mengulang pelajaran $10-$

15 menit setelah kelas selesai.

3. Melengkapi catatan untuk mengulang pelajaran.

4. Lingkungan belajar yang nyaman yaitu dengan menjaga ketenangan rumah agar dapat belajar dengan baik dan perhatian orang tua pada kegiatan belajar di rumah.

5. Melatih teknik untuk ujian sangat baik yaitu dengan berdoa sebelum mengikuti ujian.

\section{SARAN}

Berdasarkan hasil penelitian dan pembahasan yang telah dikemukakan sebelumnya, maka saran yang peneliti berikan sebagai berikut: 1) kepada guru BK di sekolah untuk dapat memberikan 
layanan-layanan bimbingan konseling sehingga siswa di sekolah mampu mempersiapkan diri dalam menghadapi ujian sehingga siswa dapat mengatasi kecemasan dalam menghadapi ujian. 2)Disarankan kepada siswa agar mempersiapkan diri dalam menghadapi ujian dengan mengulang pelajaran, mengatur waktu belajar, memiliki lingkungan belajar yang nyaman, dan melatih teknik untuk ujian sehingga kecemasan dalam menghadapi ujian bisa diminimalkan. 3) Disarankan kepada guru mata pelajaran agar mempersiapkan siswa sebelum ujian dengan membahas soal-soal ujian, dan memberikan motivasi yang positif sehingga siswa mampu menghadapi ujian dengan baik.

\section{DAFTAR RUJUKAN}

Abu Ahmadi dan Supriyono, W. 1991. Psikologi Belajar. Jakarta: Rineka Cipta

A. Muri Yusuf. 2005. 2005. Metodologi Penelitian. Padang: UNP Press.

Akhmad Sudrajat. 2008. Cara mengatasi kecemasan wordpress.com

Caron Grainger. 1999. Mengatasi Stress Bagi Para Dokter. Jakarta: Hipokrates

Hasbullah Thabrany. 1993. Rahasia Sukses Belajar. Jakarta: PT Raja Grafindo Persada

Hasbullah Thabrany. 1995. Rahasia Sukses Belajar. Jakarta: PT Raja Grafindo Persada

Hawari, D. 2002. Stress, Cemas, dan Depresi. Jakarta: Gaya Baru

Herman Nirwana, dkk. 2006. Bahan Ajar Belajar dan Pembelajaran. Padang: FIP UNP
Slameto. 2003. Belajar dan faktor-faktor yang mempengaruhinya. Jakarta: Bina Aksara

Syah, M. 1997. Psikologi Pendidikan. Bandung: Rosdakarya 